Sains Malaysiana 50(11)(2021): 3181-3191

http://doi.org/10.17576/jsm-2021-5011-03

\title{
Influence of Zeolite on the Compaction Characteristics and Shear Strength Parameters of Cemented Sand
}

(Pengaruh Zeolit pada Pencirian Pemadatan dan Parameter Kekuatan Ricih Pasir Simen)

Ghasem Norouznejad, Issa Shooshrasha*, Seyed Mohammad Mirhosseini \& Mobin AfZaLiRad

\section{ABSTRACT}

It is well known that in geotechnical engineering, soil stabilization using cement is one of the appropriate approaches for enhancing soil characteristics. With respect to zeolite, its impact on the characteristics of cemented soil has not been fully evaluated. Thus, in the current research, a set of laboratory tests including standard Proctor compaction and direct shear tests (DSTS) considering four cement contents (2, 4, 6, and 8\% of sand dry weight) and four zeolite contents $(0 \%, 30 \%, 60 \%$, and $90 \%$ of cement percentage as a replacement material) was carried out. The results indicated that the zeolite reduced Maximum Dry Density (MDD) while it increased value of Optimum Moisture Content (OMC) of cemented sand. Through the DSTs, it has been found that the replacement of cement by zeolite up to 30\%, leads to the highest values of shear strength parameters due to the occurrence of pozzolanic and chemical reactions, particularly the production of higher amounts of calcium aluminate and calcium silicate hydrates in comparison with zeolite-free samples.

Keywords: Cement; sand; shear strength parameters; standard Proctor compaction test; zeolite

\section{ABSTRAK}

Telah diketahui bahawa dalam kejuruteraan geoteknik, penstabilan tanah menggunakan simen adalah salah satu pendekatan yang sesuai untuk meningkatkan ciri tanah. Berkenaan dengan zeolit, kesannya terhadap ciri-ciri tanah simen belum dinilai sepenuhnya. Oleh itu, dalam penyelidikan semasa, satu set ujian makmal termasuk pemadatan Proktor piawai dan ujian ricih langsung (DST) mempertimbangkan empat kandungan simen (2, 4, 6 dan 8\% berat kering pasir) dan empat kandungan zeolit (0\%, $30 \%$, 60\% dan 90\% peratusan simen sebagai bahan pengganti) dijalankan. Hasil kajian menunjukkan bahawa zeolit mengurangkan Ketumpatan Kering Maksimum (MDD) sementara meningkatkan nilai Kandungan Kelembapan Optimum (OMC) pasir bersimen. Melalui DST, didapati bahawa penggantian simen dengan zeolit hingga 30\% membawa kepada nilai parameter kekuatan ricih tertinggi kerana berlakunya tindak balas pozolan dan kimia, terutama pengeluaran kalsium aluminat dan kalsium dalam jumlah yang lebih tinggi silikat hidrat berbanding dengan sampel bebas zeolit.

Kata kunci: Parameter kekuatan ricih; pasir; simen; ujian pemadatan Proktor piawai; zeolit

\section{INTRODUCTION}

Some soils in a field may not have the required qualities and characteristics for engineering purposes. These soils have a dispersive, inflatable, weak and highly permeable and compressible nature. The loose sandy soils with low strength and high collapse potential are known as one of these problematic soils. For instance, during earthquakes, there is a high probability of decreasing the strength of loose sandy soils which leads to the occurrence of liquefaction. Since in some conditions such as dense urban areas and large embankment dams, performing some improvement methods such as dynamic compaction is not possible, soil stabilization techniques are applied for enhancement of soil characteristics (Khadka et al. 2020).

Different materials such as lime, cement, silica fume, metakaolin and fly ash have been employed for the stabilization purposes (Gao et al. 2020; Hasanzadeh \& Shooshpasha 2020, 2019). One of the most practiced methods for stabilizing sandy soils is the addition of cement. This simple and reliable method has been applied in many engineering purposes such as canal lining, slope stability and foundation engineering. Some parameters 
such as cement percentage and its type, compaction method, curing period, particle size of the soil and porosity affect behavior of cemented sands. Many researchers have investigated the effect of cement as an additive on the sandy soils (Ghadakpour et al. 2020; Liu et al. 2017; Rasouli et al. 2017). Al-Aghbari et al. (2009) examined the effects of cement kiln dust and ordinary Portland cement on sandy soil and concluded that by increasing the cement percentage, the Maximum Dry Density (MDD) increased and the Optimum Moisture Content (OMC) reduced which this was more pronounced for higher cement contents. Shooshpasha and Shirvani (2015) studied the strength characteristics of sand stabilized with cement and reported that the addition of cement to sandy soil decreased displacement at failure, improved shear strength parameters, and altered the soil behavior to a more brittle one.

However, soil stabilization using cement has some disadvantages such as its high cost and the release of heavy metals. Moreover, for each ton of cement production, approximately one ton of greenhouse gas of $\mathrm{CO}_{2}$ is generated so that the emission of around $5-8 \%$ annual worldwide $\mathrm{CO}_{2}$ is due to the process of the cement production (Mola-Abasi et al. 2020). Hence, seeking new sustainable materials that can fully or at least partly substitute cement is a big challenge nowadays. Such an optimization directly contributes to the save of the natural resources, reduction of the energy consumption and conservation of the environment. Zeolite, because of its abundance in nature and eco-friendliness as well as its high potential to increase soil strength can be a good alternative for cement. Acceptable chemical, physical and environmental properties of zeolite make it desirable for the construction materials technology (Y1lmaz et al. 2007).

Zeolites are microporous, crystalline, threedimensional solids with well-defined structures (like a honeycomb), composed of a network of interconnected cages and tunnels. They have high specific surface area and are capable of storing heat between cycles of hydration and dehydration. Due to the high cationic exchange capacity, zeolite can also be utilized as an adsorbent for the elimination of contaminants in polluted water. Apart from the abundance and low cost of zeolite, it is mechanically resistant and can reduce the cementinduced environmental problems. Natural zeolite, as a volcanic material, has large amounts of reactive particles of $\mathrm{Al}_{2} \mathrm{O}_{3}$ and $\mathrm{SiO}_{2}$ which play important roles in the pozzolanic reactions for soil treatment (Mola-Abasi \& Shooshpasha 2017). It has been reported that the pozzolanic activity of natural zeolite is lower than that of silica fume while higher than that of fly ash (Poon et al. 1999). Adding zeolite as a supplementary or an additive to the construction materials not only increases the strength of the materials but also reduces their porosity. Several researchers have conducted extensive investigations on soil stabilization using zeolite (MolaAbasi et al. 2019). Yukselen-Aksoy (2010) studied the impacts of two various types of zeolite on soils and found that zeolites are mechanically stable materials which can be utilized for embankment and landfill liner applications. Firoozi et al. (2014) evaluated the impact of nano-zeolite on clay characteristics. They showed that Atterberg's limits vary with the addition of different nano-zeolite contents. Małolepszy and Grabowska (2015) studied the sulphate attack resistance of cement with zeolite and found that zeolite is very influential in reducing sulphate attack. Mola-Abasi and Shooshpasha (2016) studied the simultaneous impacts of cement and zeolite on the unconfined compressive strength (UCS) of sandy soil. They concluded that applying zeolite instead of cement improves the UCS and strain rate at failure. However, the porosity reduces and the cemented sand behavior becomes more ductile. Mola-Abasi and Shooshpasha (2017), using Group Method of Data Handling (GMDH), proposed a polynomial model for the UCS prediction of zeolite-cemented sand mixtures and reported that cement and zeolite contents are the most affective factors on the UCS.

Until now, little emphasis has been devoted to the effect of natural zeolite on the characteristics of the cemented sands. Moreover, due to the existence of loose sand and high groundwater level in Mazandaran province, Iran, the soil improvement in this area is necessary for civil engineering projects. On the other hand, the extensive geological distribution of zeolite in Iran and its unique characteristics have led geotechnical engineers to take an interest in this type of additive. Thus, in the current paper, the effects of adding various zeolite and cement contents on the geotechnical characteristics of sandy soils are investigated using laboratory tests including standard Proctor and direct shear tests (DSTs).

\section{MATERIALS AND METHODS}

The materials applied in this investigation are sand, Portland cement and natural zeolite.

\section{SAND}

The studied sand was collected from the coastal zone of Babolsar city, Mazandaran province, Iran. This sand was categorized as poorly graded sand (SP) based on the 
Unified Soil Classification System (ASTM D2487 2017) with a mean grain size, specific gravity (Gs), coefficient of uniformity and coefficient of gradation of $0.21 \mathrm{~mm}, 2.73$, 1.29 and 1.04 , respectively.

\section{CEMENT}

Portland cement type II from Neka company with Gs of 3.15 and Blaine of $305 \mathrm{~m}^{2} / \mathrm{kg}$ was employed. The physical and chemical features of this cement are presented in Table 1 .

TABLE 1. Physical and chemical characteristics of cement

\begin{tabular}{cc}
\hline Parameters & Value \\
\hline Autoclave expansion (\%) & 0.05 \\
Initial setting time (min.) & 115 \\
Compressive strength after 3 days $\left(\mathrm{kg} / \mathrm{cm}^{2}\right)$ & 185 \\
Compressive strength after 7 days $\left(\mathrm{kg} / \mathrm{cm}^{2}\right)$ & 295 \\
Compressive strength after 28 days $\left(\mathrm{kg} / \mathrm{cm}^{2}\right)$ & 397 \\
$\mathrm{SiO}_{2}(\%)$ & 21.90 \\
$\mathrm{Al}_{2} \mathrm{O}_{3}(\%)$ & 4.86 \\
$\mathrm{Fe}_{2} \mathrm{O}_{3}(\%)$ & 3.10 \\
$\mathrm{~K}_{2} \mathrm{O}(\%)$ & 0.53 \\
$\left.\mathrm{CaO}^{2} \%\right)$ & 63.30 \\
$\left.\mathrm{MgO}^{2} \%\right)$ & 1.20 \\
$\mathrm{SO}_{3}(\%)$ & 2.04 \\
$\mathrm{Na}_{2} \mathrm{O}(\%)$ & 3.07
\end{tabular}

\section{ZEOLITE}

Natural clinoptilolite type of zeolite obtained from the mines of Semnan province of Iran with particles smaller than $75 \mu \mathrm{m}$, Blaine of $400 \mathrm{~m}^{2} / \mathrm{kg}$ and Gs of 2.20 was used. The color of the used zeolite is a light cream and its specific weight is $11900 \mathrm{~N} / \mathrm{m}^{3}$. This non-plastic zeolite is categorized as ML on the basis of the Unified Soil Classification System (ASTM D2487 2017). The gradation curves of Babolsar sand and zeolite are shown in Figure 1. Table 2 presents chemical features of zeolite.

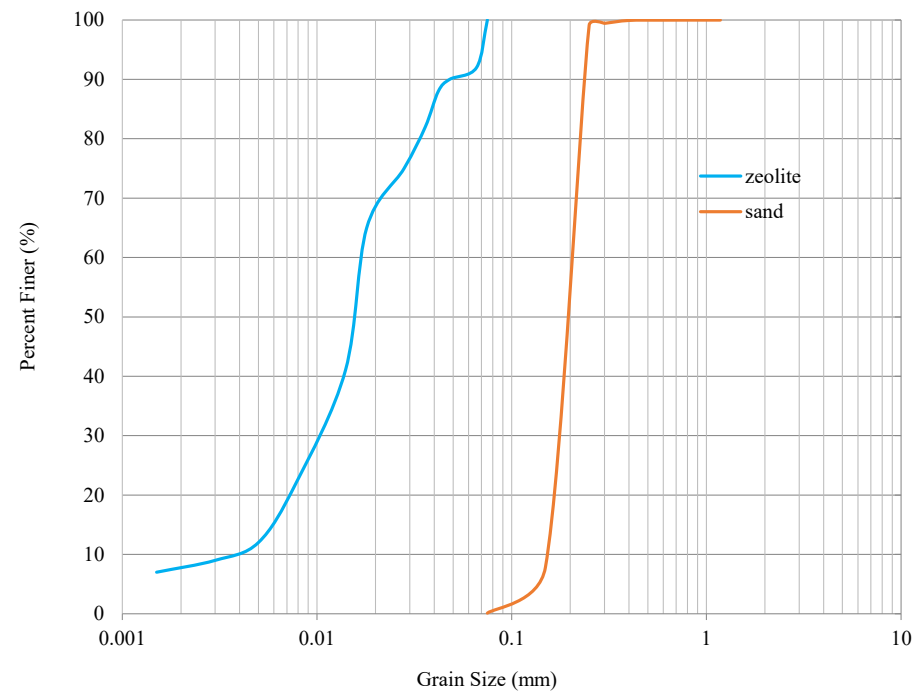

FIGURE 1. Gradation curves of zeolite and Babolsar sand 
TABLE 2. Chemical properties of zeolite

\begin{tabular}{cccccccccc}
\hline Component & $\mathrm{SiO}_{2}$ & $\mathrm{Al}_{2} \mathrm{O}_{3}$ & $\mathrm{Fe}_{2} \mathrm{O}_{3}$ & $\mathrm{~K}_{2} \mathrm{O}$ & $\mathrm{CaO}$ & $\mathrm{MgO}$ & $\mathrm{SO}_{3}$ & $\mathrm{Na}_{2} \mathrm{O}$ \\
\hline Content $(\%)$ & 67.4 & 10.80 & 0.84 & 0.19 & 1.20 & 0.33 & 0.47 & 3.70 \\
\hline
\end{tabular}

\section{SAMPLE PREPARATION}

To explore the impacts of zeolite and cement on the MDD and OMC of sand, a set of standard Proctor compaction tests was carried out according to ASTM D698 (2012). Therefore, sand, cement $(2,4,6$, and $8 \%$ by the dry weight of the sand) and zeolite $(0 \%, 30 \%, 60 \%$, and $90 \%$ of cement content, as a replacement material) were mixed with different amounts of water. The mixture was then put into a standard mold in three layers, with each layer compacted by 25 rammer blows falling down from a distance of $0.3 \mathrm{~m}$. Moisture content and weight of specimens were determined following compaction phase. Standard Proctor compaction experiments were conducted on three similar specimens for each combination of variables, and then the average value of the findings was recorded.

To prepare samples for DSTs, after weighting the sand, water, cement and zeolite amounts, the sand was mixed with cement and zeolite. The water was then subjoined based on the OMC values (which were found through the standard proctor test performed in each mixture). The process of mixing continued until a uniform blend was formed. The mixtures were compacted in three layers within the mold of $60 \times 60 \times 20 \mathrm{~mm}$. The surfaces of the first and second layers were scarified slightly to promote suitable bonding with the upper layer. To reduce the friction between sample and mold, the inside surface of the mold was lubricated before pouring the mixture into it. Hence, no crack was found in the sample after the mold removal. After removing the specimens from the mold, their heights and weights were determined. Then, the samples were placed in plastic bags and cured for 7 and 28 days in a humid room at $23 \pm 2{ }^{\circ} \mathrm{C}$ with $95 \%$ relative moisture. The DSTs were executed based on ASTM D3080 (2011) with a shear loading at a rate of 0.12 $\mathrm{mm} / \mathrm{min}$ using three various normal stresses of 0.55 , 1.20 , and $1.75 \mathrm{~kg} / \mathrm{cm}^{2}$. The failure envelope of soil was then defined according to Mohr-Coulomb failure criterion for evaluation of the shear strength parameters. Table 3 shows the variables considered in sample preparation and testing.

TABLE 3. Considered variables in this study

\begin{tabular}{ll}
\hline Properties & Description \\
\hline Soil type & Poorly graded sand \\
Cement type & Portland cement (type II) \\
Cement content & $2 \%, 4 \%, 6 \%$ and $8 \%$ by weight of dry sand \\
Type of zeolite & Natural clinoptilolite zeolite \\
Zeolite content & $0 \%, 30 \%, 60 \%$ and $90 \%$ of cement content \\
Curing condition & 7 and 28 days in a humid room \\
\hline
\end{tabular}

\section{RESULTS AND DISCUSSION}

\section{STANDARD PROCTOR COMPACTION TEST}

Table 4 presents the results of standard Proctor compaction tests for sand-cement-zeolite mixtures $(\mathrm{C}=$ cement, $\mathrm{Z}=$ zeolite). For example, $5.6 \mathrm{C} 2.4 \mathrm{Z}$ is sand with $5.6 \%$ cement and $2.4 \%$ zeolite. As observed, the addition of cement to sand results in the growth of MDD and the reduction of OMC. The MDD increase is due to the higher Gs of cement (3.15) than sand (2.73) and its smaller particles which can reduce the pores between the sand grains. The reduction of OMC may be ascribed to water self-desiccation because the relative humidity inside the paste reduces as no flow of water to the cement paste is permitted (Shooshpasha et al. 2019). Moreover, MDD decreases with replacing cement by zeolite. For example, 
the MDD values of $0.4 \mathrm{C} 3.6 \mathrm{Z}$ and $4 \mathrm{C}$ are 1.70 and $1.85 \mathrm{gr} /$ $\mathrm{cm}^{3}$, respectively. In other words, replacement of $90 \%$ of cement by zeolite leads to $8 \%$ decrease in MDD which is due to lower density of zeolite in comparison with cement and sand. Yilmaz et al. (2007) have also indicated that the existence of zeolite in the soil composition lowers the MDD. Considering environmental impacts of zeolite and its lower cost than cement, the MDD reduction by replacing cement with zeolite is not considerable. In addition, materials with low values of Gs such as zeolite can be effective as backfill for retaining structures because they apply less lateral earth pressure (Villalobos et al. 2018). It can also be seen that the OMC grows with the increase of zeolite content. It may be related to absorption of water by zeolites as they are water absorbents due to their structure and chemical features (Tatlier et al. 2018).

TABLE 4. MDD and OMC values for different samples

\begin{tabular}{ccccc}
\hline Serial number & Cement content (\%) & Zeolite content $(\%)$ & MDD $\left(\mathrm{gr} / \mathrm{cm}^{3}\right)$ & OMC (\%) \\
\hline Just sand & 0 & 0 & 1.63 & 20.4 \\
$2 \mathrm{C}$ & 2 & 0 & 1.75 & 15.5 \\
$1.4 \mathrm{C} 0.6 \mathrm{Z}$ & 1.4 & 0.6 & 1.73 & 15.8 \\
$0.8 \mathrm{C} 1.2 \mathrm{Z}$ & 0.8 & 1.2 & 1.71 & 16.2 \\
$0.2 \mathrm{C} 1.8 \mathrm{Z}$ & 0.2 & 1.8 & 1.68 & 16.5 \\
$4 \mathrm{C}$ & 4 & 0 & 1.85 & 14 \\
$2.8 \mathrm{C} 1.2 \mathrm{Z}$ & 2.8 & 1.2 & 1.77 & 15 \\
$1.6 \mathrm{C} 2.4 \mathrm{Z}$ & 1.6 & 2.4 & 1.74 & 15.5 \\
$0.4 \mathrm{C} 3.6 \mathrm{Z}$ & 0.4 & 3.6 & 1.70 & 16.2 \\
$6 \mathrm{C}$ & 6 & 0 & 1.89 & 13.5 \\
$4.2 \mathrm{C} 1.8 \mathrm{Z}$ & 4.2 & 1.8 & 1.81 & 14.3 \\
$2.4 \mathrm{C} 3.6 \mathrm{Z}$ & 2.4 & 3.6 & 1.78 & 15 \\
$0.6 \mathrm{C} 5.4 \mathrm{Z}$ & 0.6 & 5.4 & 1.74 & 15.4 \\
$8 \mathrm{C}$ & 8 & 0 & 1.93 & 12 \\
$5.6 \mathrm{C} 2.4 \mathrm{Z}$ & 5.6 & 2.4 & 1.85 & 13.1 \\
$3.2 \mathrm{C} 4.8 \mathrm{Z}$ & 3.2 & 4.8 & 1.80 & 14.2 \\
$0.8 \mathrm{C} 7.2 \mathrm{Z}$ & 0.8 & 7.2 & 1.76 & 15 \\
\hline
\end{tabular}

DSTs

As seen in Table 5, the shear strength properties of specimens improve with the increase of cement and curing time ( $\mathrm{c}=$ cohesion, $\phi=$ internal friction angle). In fact, Portland cement consists of various minerals that react at various rates with water, giving hydration products of varying crystallinity and composition, and affecting the engineering characteristics of the final product. The increase of internal friction angle with the inclusion of cement to sand may be related to the occurrence of the hydration reaction of cement. To state with more details, the cementation of tiny particles shapes larger effective 
particles, which more strongly interlock with each other. Thus, during shear, higher dilatation rates would be seen which leads to the increase of the friction angle. It can also be found that hydration of cement and its combination with sand leads to the cementation and the cohesion growth. The increase of the contact points at higher percentages of cement affects the increase of the cohesion.

Table 5 also shows that the replacement of $30 \%$ cement by zeolite improves the shear strength parameters of cemented sand significantly. It should be noted that one of the important reactions between zeolite and cement particles is a time-dependent chemical reaction, namely, pozzolanic reaction. This reaction is dependent on chemical and mineralogical compositions of cement and zeolite. In fact, chemically, both zeolite and cement contain large amounts of alumina and silica. During pozzolanic reactions, the availability of silica and alumina from amorphous minerals increases. The alumina and silica inside the zeolite structure grow reactions with cement to generate calcium aluminate hydrate $(\mathrm{CAH})$ and calcium silicate hydrate (CSH) gels (Saberian et al. 2018):

$$
\begin{gathered}
\mathrm{Ca}(\mathrm{OH})_{2}+\mathrm{Al}_{2} \mathrm{O}_{3} \rightarrow \mathrm{C}-\mathrm{A}-\mathrm{H} \\
\mathrm{Ca}(\mathrm{OH})_{2}+\mathrm{SiO}_{2} \rightarrow \mathrm{C}-\mathrm{S}-\mathrm{H}
\end{gathered}
$$

When the cement-water mixture interacts with minerals of zeolite, the zeolite alumino-silicate framework begins to decompose in a high-pH solution under the attack of $\mathrm{OH}^{-}$. Depolymerized species, such as $\left[\mathrm{Al}(\mathrm{OH})_{4}\right]^{-}$and $\left[\mathrm{SiO}(\mathrm{OH})_{3}\right]^{-}$, enter the solution and react with $\mathrm{Ca}_{2}^{+}$, creating more $\mathrm{CSH}$ and $\mathrm{CAH}$ compounds, similar to those created during the cement hydration (Mola-Abasi et al. 2017). CSH and CAH gels are the principal responsible for the hydrated cement paste strength. These gels fill the pores between sand and cement matrix in the Interfacial Transition Zone (ITZ), bind the structure together and lead to an enhancement in the strength against the shear forces. Moreover, the inclusion of very small particles of zeolite to cemented sand fills the void spaces between larger particles physically. Thus, the porosity of blended cement paste reduces and the interfacial microstructure features of the blended cement paste, the bonding between the particles and the shear strength improve (Salamatpoor et al. 2018). The increase of shear strength parameters with increasing curing period may be due to development of pozzolanic reactions. Owing to the pozzolanic reactions, the beneficial influence of zeolite on the strength of cemented sand needs the long period of curing. Thus, the shear strength parameters of samples cured for 7 days are less than the ones cured for 28 days. The increase of the curing period results in the formation of stronger cementitious surfaces on the soil particles which makes the structure of the sample more compact. While cement tends to uniformly coat the particles of sand, a portion of cement covers the surfaces positioned against the void that does not contribute to the enhancement of the shear strength. At low contents of cement, the proportion of this inactive part is high. However, it reduces at higher percentages of cement (as the surface of sand is not altered). It can be expressed that the inactive portions of the zeolite-cemented specimens are less than the zeolitefree ones and thus, the cohesion of the zeolite-cemented sand is higher. To examine the ductile/brittle behavior of specimens, brittleness index $\left(\mathrm{I}_{\mathrm{B}}\right)$ introduced by Bishop (1971) was employed:

$$
\mathrm{I}_{\mathrm{B}}=\frac{\tau_{p}-\tau_{r}}{\tau_{p}}
$$

in which $\tau_{p}$ and $\tau_{r}$ are peak and residual shear strengths, respectively. When $\mathrm{I}_{B}$ tends to zero, it shows higher ductility. Figure 2 shows variation of $I_{B}$ with normal stress for sand- zeolite- cement $(\mathrm{C}=8 \%)$ mixtures. As seen, $I_{B}$ decreases with increasing normal stress. In other words, the zeolite- cemented sand becomes more ductile with the increased normal stress. In addition, the increase of $I_{B}$ with the curing time may be because of the completion of pozzolanic reactions leading to strengthening the chemical bonds in matrix of mixture. In regard to zeolite, it can be observed that zeolite increases ductility of the samples. This shows that zeolite changes the mineralogy of zeolite-cement-sand mixture and makes less difference between $\tau_{p}$ and $\tau_{r}$. The presence of cement in the sand causes the shear stress-shear strain to reach its maximum value, which indicates that the cracking has occurred, but the presence of zeolite leads to the more ductile behavior. Similar results were found for other cases. It can be observed from Table 5 and Figures 3 to 6 that for zeolite contents more than $30 \%$, the shear strength parameters decrease. To clarify in more depth, it can be stated that in the hydration of cement and pozzolanic reactions, the amounts of $\mathrm{SiO}_{2}$ and $\mathrm{Al}_{2} \mathrm{O}_{3}$ in reaction with $\mathrm{CaO}$ have a significant influence on strength (Mola-Abasi et al. 2019). For the sufficient amount of $\mathrm{CaO}$, increasing $\mathrm{SiO}_{2}$ and $\mathrm{Al}_{2} \mathrm{O}_{3}$ will result in a more active pozzolanic reaction that improves strength. With the increase of cement percentage, the $\mathrm{SiO}_{2}$ and $\mathrm{Al}_{2} \mathrm{O}_{3}$ values (reaction particles) increase while their total value will be lower than $\mathrm{CaO}$. Therefore, it is anticipated that if the values of these particles become higher, shear strength will enhance as well. In this case, 
if zeolite percentage increases, the $\mathrm{SiO}_{2}$ and $\mathrm{Al}_{2} \mathrm{O}_{3}$ will grow but $\mathrm{CaO}$ reduces. When zeolite replacement is below $30 \%$, pozzolanic particles are more efficient and when it becomes more than $30 \%, \mathrm{CaO}$ particles have higher influence. As presented in Table 6, with replacing $30 \%$ cement by zeolite, the sum of $\mathrm{Al}_{2} \mathrm{O}_{3}$ and $\mathrm{SiO}_{2}$ $(35.5+6.7=42.2 \%)$ is close to $\mathrm{CaO}$ content $(44.6 \%)$. This is indicative of the highest improvement of shear strength parameters at this zeolite content. If particles of $\mathrm{SiO}_{2}$ and $\mathrm{Al}_{2} \mathrm{O}_{3}$ become more than the particles of $\mathrm{CaO}$ (specimens with more than $30 \%$ replaced zeolite), pozzolanic reactions and consequently, the amounts of $\mathrm{CSH}$ and $\mathrm{CAH}$ reduce due to the decrease of $\mathrm{CaO}$ and cement amounts.

TABLE 5. The values of shear strength parameters for sand with various percentages of zeolite and cement after 7 and 28 days

\begin{tabular}{|c|c|c|c|c|}
\hline \multirow[t]{2}{*}{ Serial number } & \multicolumn{2}{|c|}{7 days } & \multicolumn{2}{|c|}{28 days } \\
\hline & $\mathrm{c}\left(\mathrm{kg} / \mathrm{cm}^{2}\right)$ & $\phi$ (Degrees) & $\mathrm{c}\left(\mathrm{kg} / \mathrm{cm}^{2}\right)$ & $\phi$ (Degrees) \\
\hline Just sand & 0 & 35.2 & 0 & 35.2 \\
\hline $2 \mathrm{C}$ & 0.14 & 38.8 & 0.24 & 47.1 \\
\hline $1.4 \mathrm{C} 0.6 \mathrm{Z}$ & 0.17 & 39.2 & 0.28 & 48.3 \\
\hline $0.8 \mathrm{C} 1.2 \mathrm{Z}$ & 0.12 & 36.6 & 0.19 & 45.4 \\
\hline $0.2 \mathrm{C} 1.8 \mathrm{Z}$ & 0.10 & 34.9 & 0.16 & 44.1 \\
\hline $4 \mathrm{C}$ & 0.25 & 40.6 & 0.42 & 49.5 \\
\hline $2.8 \mathrm{C} 1.2 \mathrm{Z}$ & 0.36 & 42.2 & 0.46 & 50.2 \\
\hline $1.6 \mathrm{C} 2.4 \mathrm{Z}$ & 0.24 & 41 & 0.38 & 47.9 \\
\hline $0.4 \mathrm{C} 3.6 \mathrm{Z}$ & 0.18 & 40.3 & 0.35 & 45.6 \\
\hline $6 \mathrm{C}$ & 0.30 & 43.8 & 0.44 & 50 \\
\hline $4.2 \mathrm{C} 1.8 \mathrm{Z}$ & 0.34 & 48.2 & 0.49 & 51.1 \\
\hline $2.4 \mathrm{C} 3.6 \mathrm{Z}$ & 0.32 & 47.9 & 0.45 & 50.6 \\
\hline $0.6 \mathrm{C} 5.4 \mathrm{Z}$ & 0.29 & 45.5 & 0.40 & 48.8 \\
\hline $8 \mathrm{C}$ & 0.41 & 47 & 0.52 & 52.4 \\
\hline $5.6 \mathrm{C} 2.4 \mathrm{Z}$ & 0.47 & 52.6 & 0.64 & 55.1 \\
\hline $3.2 \mathrm{C} 4.8 \mathrm{Z}$ & 0.42 & 50.7 & 0.60 & 53.8 \\
\hline $0.8 \mathrm{C} 7.2 \mathrm{Z}$ & 0.38 & 49.9 & 0.55 & 52.7 \\
\hline
\end{tabular}


TABLE 6. Chemical characteristics of the cement replaced by $30 \%$ zeolite

\begin{tabular}{cccc}
\hline Content & $\mathrm{SiO}_{2}(\%)$ & $\mathrm{Al}_{2} \mathrm{O}_{3}(\%)$ & $\mathrm{CaO}(\%)$ \\
\hline 0.7 cement & 15.3 & 3.4 & 44.3 \\
0.3 zeolite & 20.2 & 3.2 & 0.3 \\
Total & 35.5 & 6.7 & 44.6 \\
\hline
\end{tabular}

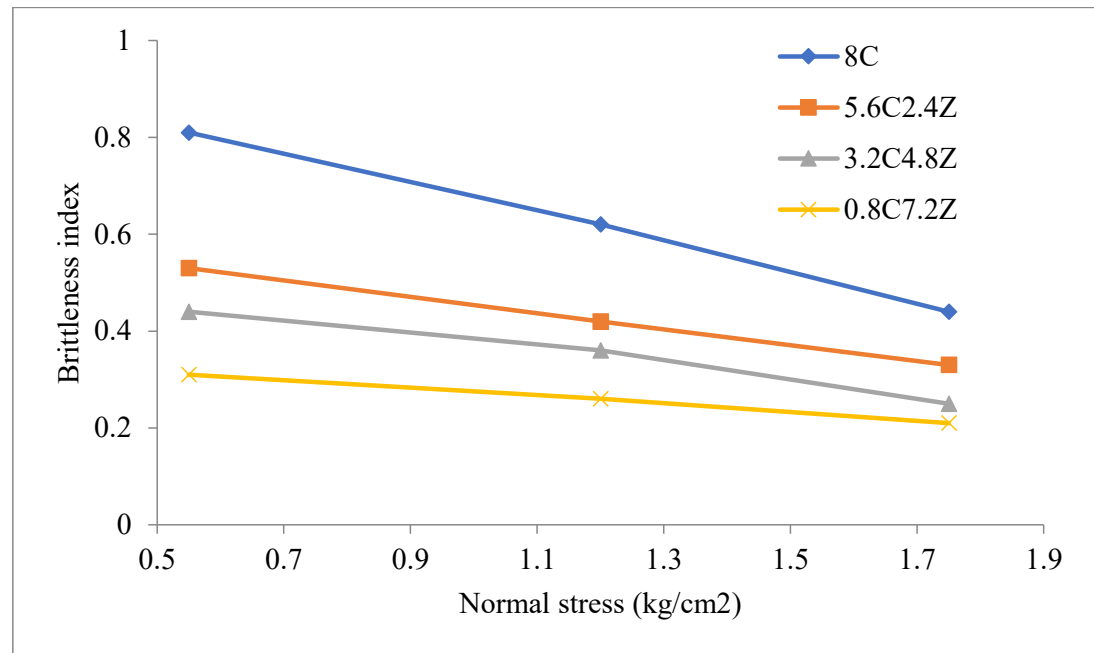

(a)

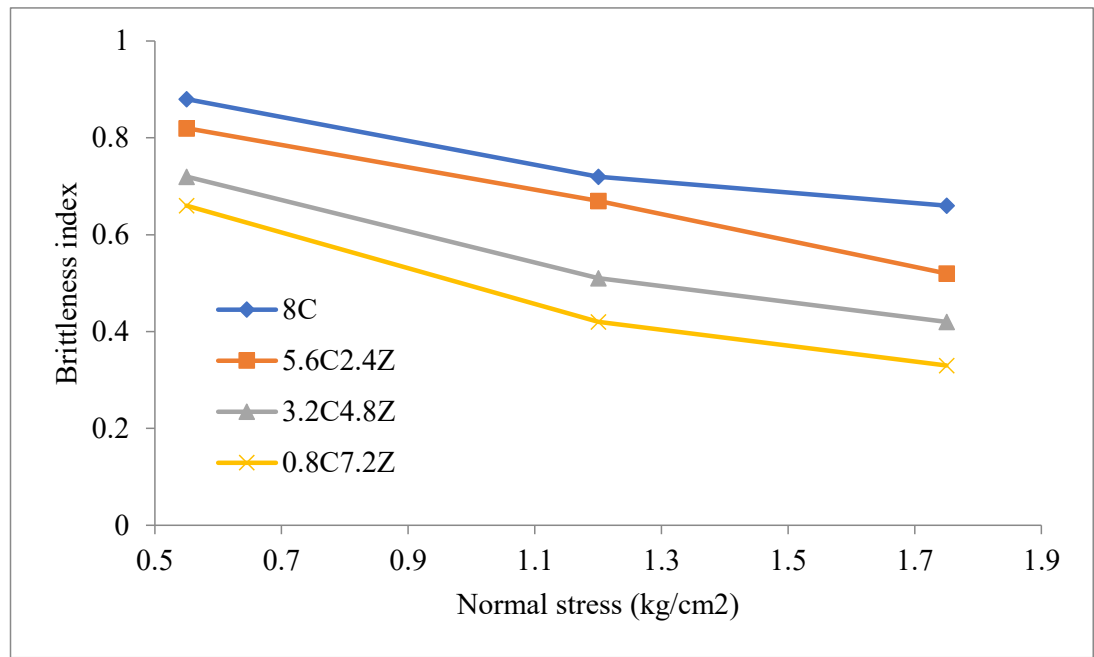

(b)

FIGURE 2. Variation of brittleness index with normal stress for sand- cement $(\mathrm{C}=8 \%$ )- zeolite mixture (a) 7 days (b) 28 days of curing period 


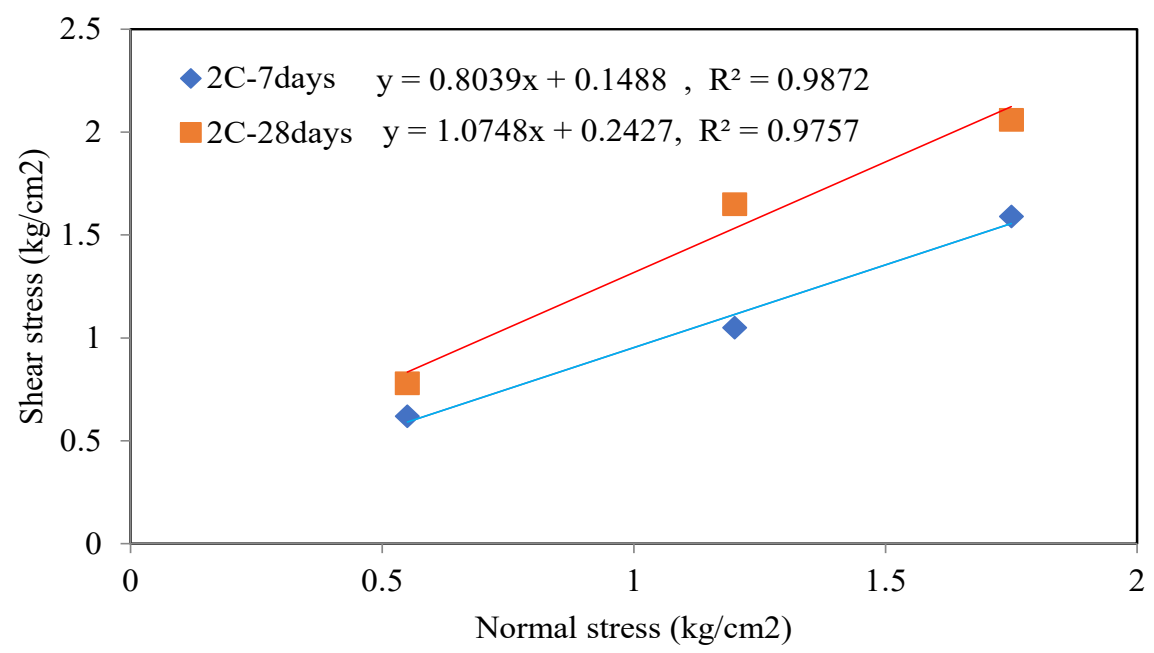

FIGURE 3. Variation of shear stress with normal stress for sand with $2 \%$ cement $(2 \mathrm{C})$

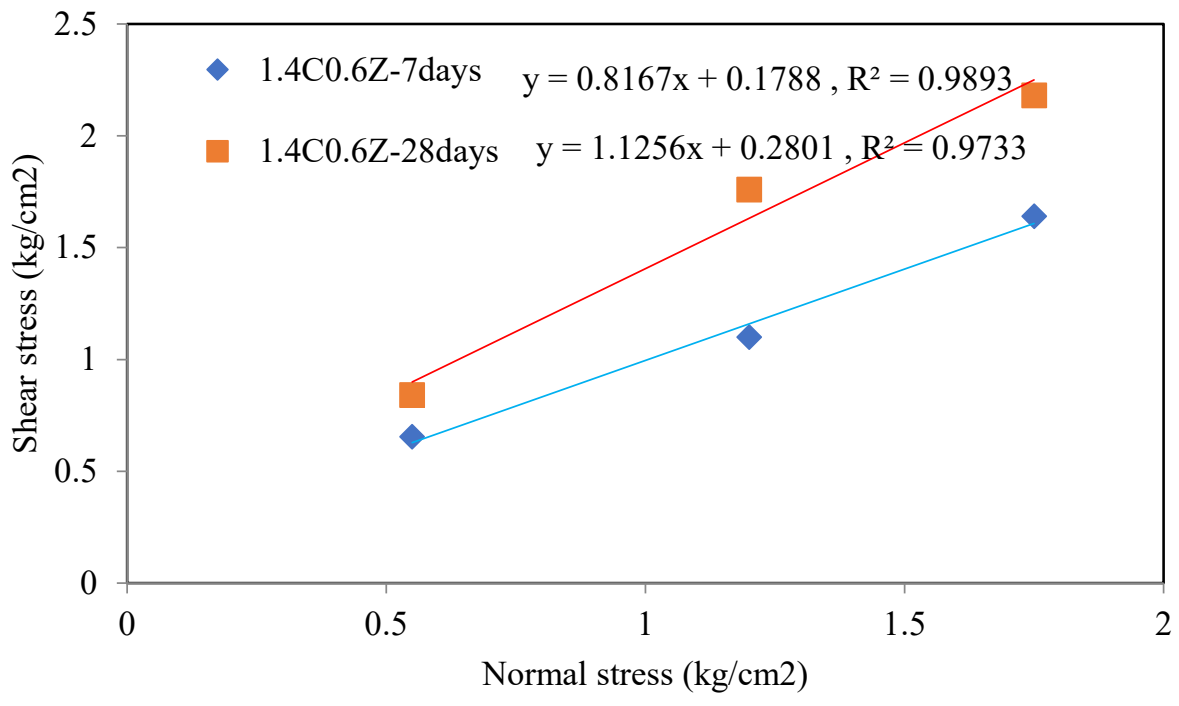

FIGURE 4. Variation of shear stress with normal stress for sand with $1.4 \%$ cement and $0.6 \%$ zeolite $(1.4 \mathrm{C} 0.6 \mathrm{Z})$

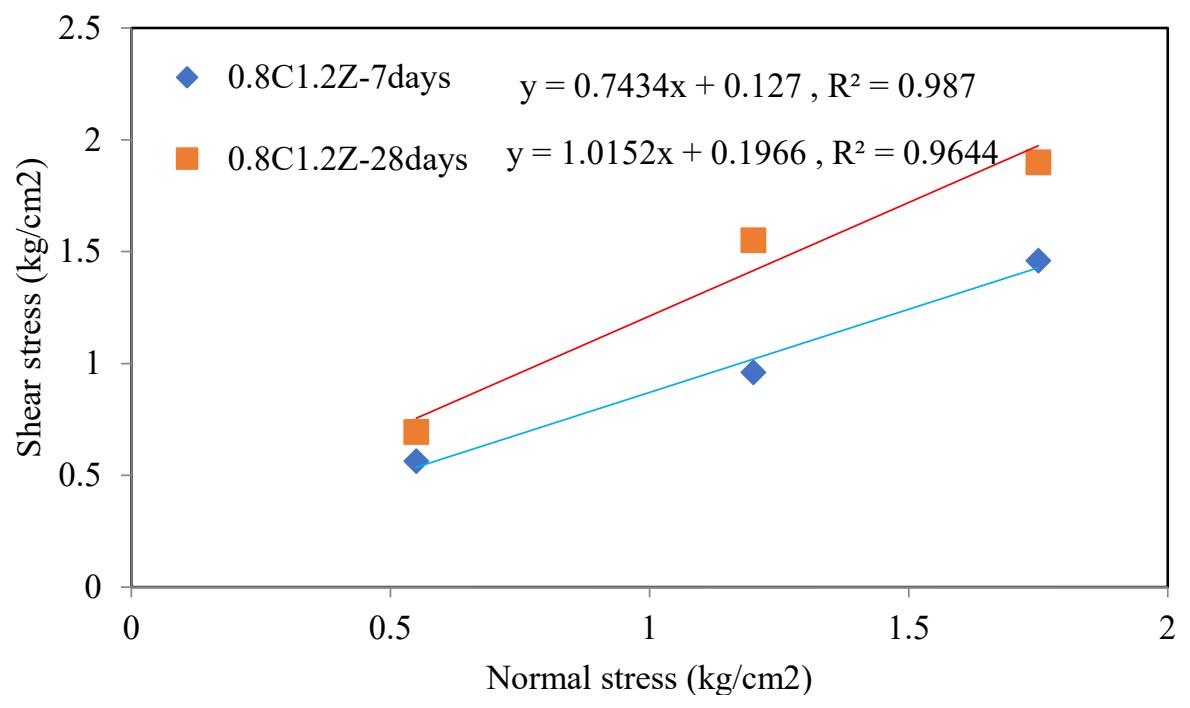

FIGURE 5. Variation of shear stress with normal stress for sand with $0.8 \%$ cement and $1.2 \%$ zeolite $(0.8 \mathrm{C} 1.2 \mathrm{Z})$ 


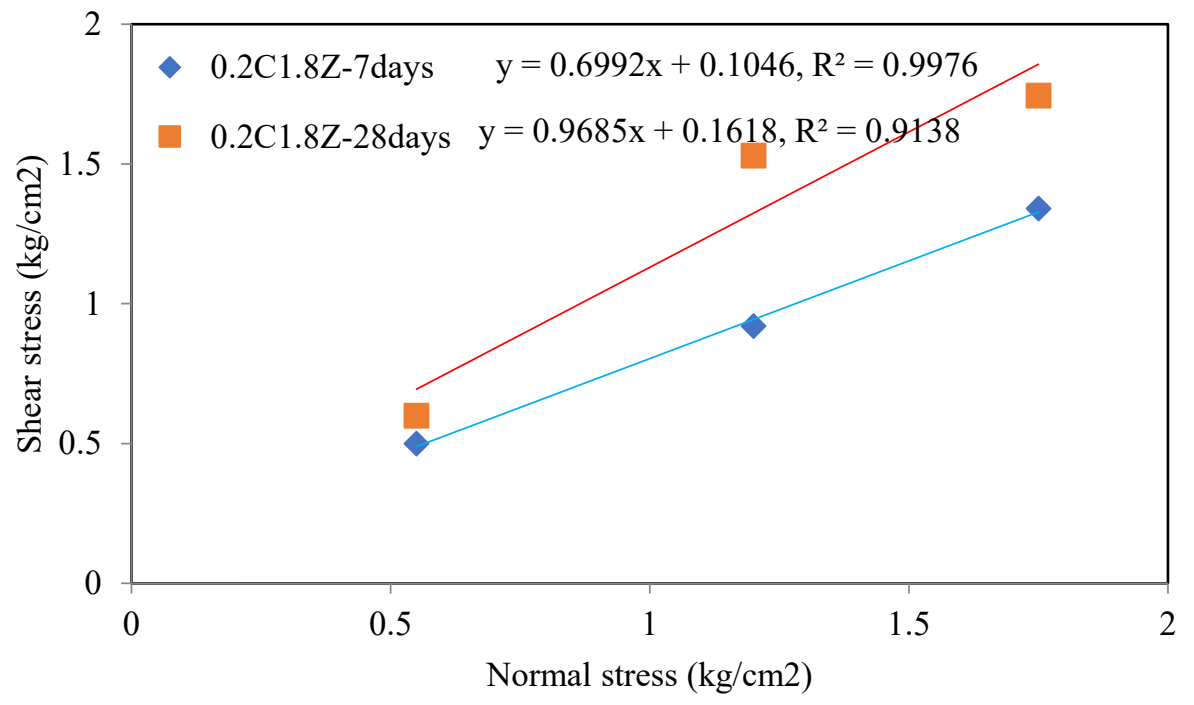

FIGURE 6. Variation of shear stress with normal stress for sand with $0.2 \%$ cement and $1.8 \%$ zeolite $(0.2 \mathrm{C} 1.8 \mathrm{Z})$

\section{CONCLUSION}

In this research, zeolite was used as a natural and an inexpensive pozzolan-based mineral to improve the compaction characteristics and shear strength parameters of the cemented sand. The most significant results obtained by this study are as follows: The addition of cement into the sand increased the MDD through filling the spaces between sand particles and its greater specific gravity than sand while with the inclusion of zeolite into the cemented sand, the MDD decreased due to its lower density than that of the cement. Shear strength parameters increased with increasing cement, normal stress and curing time. The optimum amount of cement replacement by zeolite for the highest improvement in the shear strength parameters was achieved at $30 \%$. In other words, substitution of $30 \%$ zeolite is sufficient to produce a noticeable gain in shear strength. The zeolite in the presence of humidity develops compounds with cement properties such as calcium aluminate hydrate and calcium silicate hydrate gels which can lead to the improvement of shear strength through binding the matrix, filling the pores and increasing density of the transition zone. The process of cement production is time-consuming and expensive in Iran. In addition, cement production uses lots of energy and generates carbon dioxide, nitrogen oxide and particulate air suspensions. However, zeolite production is cheaper, requires less energy and also induces less pollution. Furthermore, from an economic viewpoint, huge reserves of zeolite can be found in Iran.
Therefore, using zeolite can be an appropriate option to decrease consumption of cement.

\section{REFERENCES}

Al-Aghbari, M.Y., Mohamedzein, Y.A. \& Taha, R. 2009. Stabilisation of desert sands using cement and cement dust. Proceedings of the Institution of Civil Engineers-Ground Improvement 162: 145-151.

ASTM Standards D2487. 2017. Standard Practice for Classification of Soils for Engineering Purposes (Unified Soil Classification System), West Conshohocken, United States.

ASTM Standards D698. 2012. Standard Test Methods for Laboratory Compaction Characteristics of Soil using Standard Effort, West Conshohocken, United States.

ASTM Standards D3080. 2011. Standard Test Method for Direct Shear Test of Soils under Consolidated Drained Conditions, West Conshohocken, United States.

Bishop, A.W. 1971. The influence of progressive failure on the choice of stability analysis. Geotechnique 21(2): 168-172.

Firoozi, A.A., Taha, M.R., Firoozi, A.A. \& Khan, T.A. 2014. Assessment of nano-zeolite on soil properties. Australian Journal of Basic \& Applied Sciences 8: 292-295.

Gao, M., Yuan, F., Xue, Y. \& Guan, P. 2020. Effect of polyacrylamide on compression rate of lime stabilized soil. Sains Malaysiana 49(8): 1925-1934.

Ghadakpour, M., Choobbasti, A.J. \& Kutanaei, S.S. 2020. Investigation of the Kenaf fiber hybrid length on the properties of the cement-treated sandy soil. Transportation Geotechnics 22: 100301.

Hasanzadeh, A. \& Shooshpasha, I. 2020. Influence of silica fume on the geotechnical characteristics of cemented sand. 
Geotechnical and Geological Engineering. https://doi. org/10.1007/s10706-020-01436-w.

Hasanzadeh, A. \& Shooshpasha, I. 2019. Effects of silica fume on cemented sand using ultrasonic pulse velocity. Journal of Adhesion Science and Technology 33: 1184-1200.

Khadka, S.D., Jayawickrama, P.W., Senadheera, S. \& Segvic, B. 2020. Stabilization of highly expansive soils containing sulfate using metakaolin and fly ash based geopolymer modified with lime and gypsum. Transportation Geotechnics 23: 100327.

Liu, Z., Jia, J., Feng, W., Ma, F. \& Zheng, C. 2017. Shear strength of cemented sand gravel and rock materials. Sains Malaysiana 46(11): 2101-2108.

Małolepszy, J. \& Grabowska, E. 2015. Sulphate attack resistance of cement with zeolite additive. Procedia Engineering 108: 170-176.

Mola-Abasi, H. \& Shooshpasha, I. 2017. Polynomial models controlling strength of zeolite-cement- sand mixtures. Scientia Iranica 24: 526-536.

Mola-Abasi, H. \& Shooshpasha, I. 2016. Influence of zeolite and cement additions on mechanical behavior of sandy soil. Journal of Rock Mechanics and Geotechnical Engineering 8: 746-752.

Mola-Abasi, H., Semsani, S.N., Saberian, M., Khajeh, A., Li, J. \& Harandi, M. 2020. Evaluation of the long-term performance of stabilized sandy soil using binary mixtures: A micro- and macro-level approach. Journal of Cleaner Production 267: 122209.

Mola-Abasi, H., Saberian, M. \& Li, J. 2019. Prediction of compressive and tensile strengths of zeolite-cemented sand using porosity and composition. Construction and Building Materials 202: 784-795.

Mola-Abasi, H., Kordtabar, B. \& Kordnaeij, A. 2017. Parameters controlling strength of zeolite-cement-sand mixture. International Journal of Geotechnical Engineering 11: 72-79.

Poon, C.S., Lam, L., Kou, S.C. \& Lin, Z.S. 1999. A study on the hydration rate of natural zeolite blended cement pastes. Construction and Building Materials 13: 427-432.

Rasouli, H., Takhtfiroozeh, H., Taghavi Ghalesari, A. \& Hemati, R. 2017. Bearing capacity improvement of shallow foundations using cement-stabilized sand. Key Engineering Materials 723: 795-800.

Saberian, M., Moradi, M., Vali, R. \& Li, J. 2018. Stabilized marine and desert sands with deep mixing of cement and sodium bentonite. Geomechanics and Engineering 14: 553-562.
Salamatpoor, S., Jafarian, Y. \& Hajiannia, A. 2018. Improving shallow foundations resting on saturated loose sand by a zeolite-cement mixture: A laboratory study. Scientia Iranica 25: 2063-2076.

Shooshpasha, I. \& Shirvani, R.A. 2015. Effect of cement stabilization on geotechnical properties of sandy soils. Geomechanics and Engineering 8: 17-31.

Shooshpasha, I., Hasanzadeh, A. \& Kharun, M. 2019. The influence of micro silica on the compaction properties of cemented sand. IOP Conference Series: Materials Science and Engineering 675: 1-8.

Tatlier, M., Munz, G. \& Henninger, S.K. 2018. Relation of water adsorption capacities of zeolites with their structural properties. Microporous and Mesoporous Materials 264: 70-75.

Villalobos, F.A., Leiva, E.A., Jerez, O. \& Poblete, M.E. 2018. Experimental study of the fine particles effect on the shear strength of tuff zeolites. Revista de la Construcción 17: 23-37.

Yılmaz, B., Ucar, A., Oteyaka, B. \& Uz, V. 2007. Properties of zeolitic tuff (clinoptilolite) blended portland cement. Building and Environment 42: 3808-3815.

Yukselen-Aksoy, Y. 2010. Characterization of two natural zeolites for geotechnical and geoenvironmental applications. Applied Clay Science 50: 130-136.

Ghasem Norouznejad, Issa Shooshpasha*, Seyed Mohammad Mirhosseini \& Mobin Afzalirad

Department of Civil Engineering

Islamic Azad University

Arak Branch, Arak

Iran

Mobin Afzalirad

Department of Civil Engineering

Islamic Azad University

Qaemshahr Branch, Qaemshahr

Iran

*Corresponding author; email: shooshpasha@nit.ac.ir

Received: 30 September 2020

Accepted: 7 March 2021 